\title{
Implementasi pendidikan antikorupsi pada mata pelajaran PPKn berbasis project citizen di Sekolah Menengah Atas
}

\author{
Sutrisno \\ PPKn Universitas Muhammadiyah Ponorogo \\ sutrisno.afiq@gmail.com
}

\begin{abstract}
This research was aimed at describing the implementation of anti-corruption education on citizenship education through project citizen-based activity. It is descriptive inquiry conducted at SMA Muhammadiyah 1 Ponorogo. The result was that the implementation of anti-corruption education was conducted through studying problems relating corruption resulting in presentation panels consist of 4 sections namely problem, alternative policy, proposed solution, and action plan section. Through these activities, it was intended that students would acquired some desired attitudes such as honesty, care, self-help, discipline, responsibility, hard work, humbleness, courage and justice.
\end{abstract}

Keywords: anti-corruption education, citizenship education, project citizen.

\section{Pendahuluan}

Korupsi merupakan masalah krusial yang terjadi di Indonesia. Korupsi berkembang dengan sangat pesat dan meluas di berbagai aspek kehidupan masyarakat. Tentu diperlukan upaya yang efektif dalam menyelesaikan korupsi di Indonesia. Upaya pengenalan tentang budaya antikorupsi haruslah dilakukan sejak dini. Salah satunya melalui dunia pendidikan, baik sekolah dasar maupun sekolah menengah atas. Upaya pendidikan antikorupsi tentu akan menjadi solusi yang efektif dalam meminimalkan tindak pidana korupsi. Pemerintah Indonesia memulai upayanya pada tahun 2009 melalui Kementerian Pendidikan Nasional mengupayakan adanya bahan ajar berupa modul pendidikan antikorupsi pada sekolah dasar sampai sekolah menengah atas. Namun demikian upaya tersebut tentu juga belum menjadi jaminan dalam mengembangkan muatan materi pendidikan antikorupsi pada sekolah-sekolah tersebut.

Bentuk upaya penanggulangan korupsi tentu menjadi kajian yang sangat menarik di dunia saat ini. Permasalahan korupsi tentu menjadi pembahasan pertama di seluruh dunia. Setiap waktu setiap jam tentu masyarkat selalu berhubungan dengan birokrasi pemerintahan yang pada umumnya sangat rentan adanya tidak pidana korupsi. Tidak menutup kemungkinan juga bahwa setiap interaksi manusia baik di lingkungan keluarga, sekolah, masyarakat, bahkan di media sosial tentu terjadi unsur tindak pidana korupsi. Maka dari itu perlu adanya strategi dan upaya maksimal oleh pemerintah untuk meminimalkan hal itu. Pemerintah memandang lembaga pendidikan menjadi salah satu lembaga yang efektif dalam memperkenalkan bentuk dan budaya korupsi pada peserta didik sejak dini yakni melalui Pendidikan Antikorupsi. Dengan pengetahuan antikorupsi sejak dini diharapkan mampu mencetak calon pemimpin bangsa yang berjiwa antikorupsi di Indonesia. Maka dari itu sangat diperlukan upaya yang strategis dan sistematis dalam mengajarkan materi pendidikan antikorupsi pada peserta didik sehingga akan benar-benar terbentuk para peserta didik yang berkarakter berdasarkan nilai-nilai antikorupsi. Dengan demikian nilai-nilai dasar dalam pembentukan peraturan perundang-undangan khususnya pendidikan antikorupsi harus 
menggunakan Pancasila sebagai landasan filosofis yakni sebagai pandangan hidup, kesadaran dan cita-cita hukum sehingga akan tercapai standarisasi konstitusi yang berlandaskan nilai dasar negara Pancasila sebagai sistem pendidikan yang murni (Sutrisno, 2016).

Pendidikan tidak lepas dari proses kehidupan manusia. Melalui pendidikan manusia mengetahui bagaimana hakikat mereka bisa hidup dan bisa berinteraksi secara sosial. Oleh karena itu selama ada kehidupan, selama itu manusia akan selalu ada di dunia. Salah satu bentuk penyelesaian masalah manusia yakni dengan pendidikan. Pendidikan saat ini tentu menjadi kunci dari berbagai masalah yang dialami bangsa Indonesia saat ini. Ketika manusia mampu memahami dimensi pendidikan yang sebenarnya maka manusia tersebut akan bisa memanfaatkan setiap waktu di dalam kehidupannya. Berbagai masalah yang terjadi di Indonesia saat ini tentu membutuhkan penyelesaian yang cepat dan konkrit. Tentu hal ini dapat dilakukan melalui pendidikan. Permasalahan korupsi tentu menjadi objek kajian yang menarik untuk dikaji secara umum.

Pendidikan antikorupsi adalah salah satu upaya yang dilakukan pemerintah dalam menanamkan sikap antikorupsi pada peserta didik di lingkungan sekolah. Korupsi sendiri merupakan tidak perbuatan yang merugikan orang banyak dengan memanfaatkan jabatan untuk memperoleh keuntungan secara pribadi. Korupsi dilakukan dengan cara-cara yang tidak sesuai aturan, seperti: penyuapan, pemerasan dan penipuan berpotensi terjadi pada sektor pemerintahan yang akan menjadi penyakit yang merusak semua tatanan kehidupan (Hamilton-Hart, 2001). Pada dasarnya pendidikan anti korupsi dapat diartikan sebagai salah satu program pendidikan yang menjelaskan dan menanggulangi berbagai korupsi yang terjadi di kalangan masyarakat dengan upaya penanaman sedini mungkin jiwa antikorupsi dengan tujuan untuk membangun dan meningkatkan kepedulian warga negara terhadap bahaya dan akibat dari tindakan korupsi. Pendidikan antikorupsi memiliki tiga tujuan, pertama, membentuk pengetahuan dan pemahaman bentuk korupsi dan aspekaspeknya. Kedua, mengubah persepsi dan sikap terhadap korupsi. Ketiga, membentuk keterampilan dan kecakapan baru yang ditujukan untuk melawan korupsi (Hakim, 2012).

Sebagai perbandingan, pengembangan pendidikan antikorupsi di Lithuania dilakukan secara sistematis sejak tahun 2015 dengan memberikan pemahaman pada peserta didik untuk bisa membedakan antara kejahatan korupsi dengan kejahatan lain, memberikan argumen yang logis dan rasional mengapa korupsi dianggap sebagai suatu kejahatan, serta menunjukkan cara-cara yang bisa ditempuh dalam mengurangi terjadinya tindak pidana korupsi. Ada beberapa hal yang perlu dikembangkan dalam proses pendidikan antikorupsi di kelas yakni pengetahuan tentang korupsi, pengembangan sikap antikorupsi, perubahan sikap antikorupsi, pendidikan moral, dan pengembangan karakter antikorupsi (Ministry of Education and Science of the Republic of Lithuania, 2006, p. 22).

Selain hal tersebut tentu juga diperlukan adanya penanaman sikap antikorupsi pada peserta didik dalam setiap proses pembelajaran. Sikap merupakan komponen penting dalam mengembangkan budaya atau karakter peserta didik dalam melakukan kebaikan. Menurut Sax (1997, p. 493) sikap merupakan "a prefence along a dimension of 
favourableness to unfavourableness to a particular group, institution, concept, or object."

Pemerintah haruslah menjamin dan mengawal pendidikan antikorupsi agar tujuan dan target awal dalam implementasi pendidikan antikorupsi benar-benar bisa dipahami dan dicerna dengan baik oleh guruguru pengampu mata pelajaran yang berhubungan dengan pendidikan antikorupsi. Tidak hanya guru saja namun peran lembaga sekolah dalam pelaksanaan dan pengelolaan sistem pendidikan juga harus turut ambil bagian. Tanpa adanya kerja sama yang baik antara guru dengan lembaga sekolah yakni kepala sekolah sebagai pengambil kebijakan secara langsung, mustahil program-program pendidikan antikorupsi yang diwacanakan pemerintah sejak tahun 2009 sampai sekarang bisa tercapai.

Mata pelajaran Pendidikan Pancasila dan Kewarganegaraan (PPKn) merupakan mata pelajaran wajib dalam kurikulum 2013. Mata pelajaran ini tentu bermuatan materi yang berhubungan dengan pendidikan antikorupsi. Mengingat bahwa materi pendidikan antikorupsi belum berdiri sendiri sebagai mata pelajaran wajib. Sama halnya dengan pendidikan karakter bahwa walaupun belum menjadi mata pelajaran sendiri yang diajarkan dalam proses pembelajaran di sekolah, akan tetapi materi pendidikan antikorupsi dan materi pendidikan karakter harus diintegrasikan dengan materi-materi mata pelajaran lain, khususnya pada mata pelajaran Pendidikan Agama dan PPKn. Sejalan dengan hal tersebut tentu mata pelajaran PPKn cocok sebagai media transformasi ilmu-ilmu pada Pendidikan Antikorupsi dalam setiap pembelajaran di kelas.

PPKn merupakan mata pelajaran yang memuat nilai-nilai karakter kebangsaan.
PPKn merupakan pendidikan yang berfungsi untuk membangun kesadaran warga negara dalam menjalankan hak dan kewajiban sebagai warga negara dalam upaya membentuk identitas terhadap warga negara bagi suatu bangsa. Pembelajaran PPKn harus bertumpu pada kemampuan dasar kewarganegaraan (civic competence) untuk semua jenjang. Untuk itu agar pembelajaran efektif dan mampu membekali siswa dengan pengetahuan dan mencapai kemampuan dasar kewarganegaraan, maka dalam mengembangkan kegiatan pembelajaran perlu memperhatikan beberapa hal. Pertama, Kegiatan Pembelajaran PPKn disusun untuk memberikan bantuan kepada para pendidik (guru), agar dapat melaksanakan proses pembelajaran secara profesional. Kedua, kegiatan pembelajaran PPKn memuat rangkaian kegiatan yang harus dilakukan oleh peserta didik secara berurutan untuk mencapai kompetensi dasar. Ketiga, penentuan urutan kegiatan pembelajaran PPKn harus sesuai dengan hierarki konsep materi pembelajaran. Keempat, rumusan pernyataan dalam kegiatan pembelajaran PPKn minimal mengandung dua unsur yang mencerminkan pengelolaan pengalaman belajar peserta didik.

PPKn memiliki peran penting dalam upaya menumbuhkan karakter generasi muda yang berpikir kritis tentang isu-isu global untuk bisa mengeksplorasi, mengembangkan dan mengekspresikan nilai-nilai dan pendapat mereka sendiri. Hal tersebut tentu sama dengan yang diungkapkan (Zahabioun, Yousefy, Yarmohammadian, \& Keshtiaray, 2013) tentang Pendidikan Kewarganegaraan global bahwa:

Education for Global Citizenship gives children and young people the opportunity to develop critical thinking about complex global 
issues in the safe space of the classroom, encourages children and young people to explore, develop and express their own values and opinions, whilst listening to and respecting other people's points of view, to care about the planet and to develop empathy with, and an active concern for, those with whom they share it.

Tentu hal ini menunjukkan bahwa pendidikan harus benar-benar mampu untuk mengembangkan karakteristik warga negara yang berdasarkan karakter suatu negara. Untuk menumbuhkan karakteristik warga negara dalam proses pembelajaran PPKn tentu dibutuhkan Inovasi. Inovasi pembelajaran PPKn dapat dilakukan dengan penerapan pendekatan pembelajaran PKn dari pendekatan yang berorientasi pada isi (content based curriculum) ke arah yang lebih menekankan pada proses (process based curriculum). Gagasan ini dimaksudkan agar melalui PPKn dapat terbentuk warga negara yang lebih mandiri dalam memahami dan mencari solusi terhadap masalah yang dihadapi serta mampu mengambil keputusankeputusan yang terbaik bagi dirinya, lingkungan serta masyarakatnya. Kemampuan ini telah dirangkum menjadi tiga sasaran pembelajaran PPKn yang dikenal pula sebagai orientasi tujuan pembelajaran PPKn untuk pembentukan warganegara yang demokratis, ialah membentuk warga negara yang baik dan cerdas (good and smart citizen), partisipatif (participative citizen), dan bertanggungjawab (responsible citizen)Wahab \& Sapriya (2011, pp. 327328). Dengan demikian diharapkan melalui proses pembelajaran yang inovatif, efektif dan efisien dengan berbagai pendekatan yang digunakan mampu mengimplementasikan pendidikan antikorupsi pada mata pelajaran PPKn dangan baik.

Mata pelajaran PPKn memiliki misi yang sangat mulia. Berkaitan dengan misi PKn tersebut, Maftuh (2008, p. 137) berpendapat bahwa dengan tuntutan perkembangan masyarakat dan kehidupan bernegara yang demikian maju dengan segala tantangannya, Pendidikan Kewarganegaraan pada masa sekarang ini memiliki misi sebagai berikut: 1) PKn sebagai Pendidikan Politik; 2) PKn sebagai Pendidikan Nilai; 3) PKn sebagai Pendidikan Nasionalisme; 4) PKn sebagai Pendidikan Hukum; 5) PKn sebagai Pendidikan Multikultural; dan 6) PKn sebagai Pendidikan Resolusi Konflik.

Misi tersebut tentu menjadi salah satu tujuan bagaimana mata pelajaran PPKn bisa menjadi tolak ukur dalam pengimplementasian nilai-nilai antikorupsi pada peserta didik sebagai salah satu dari pendidikan nilai yang perlu dikembangkan. Sebagai wujud penerapan pendidikan antikorupsi pada mata pelajaran PPKn sebagai salah satu dari pendidikan nilai. Maka haruslah dapat diimplementasikan secara maksimal dalam setiap proses pembelajaran. Kurikulum 2013 menjelaskan bawah upaya proses pembelajaran yang dikembangkan dalam setiap proses pembelajaran haruslah berorientasi pada penerapan nilai-nilai karakter kebangsaan dengan berlandaskan nilai-nilai dasar negara Pancasila. Pengembangan aspek sosial, pengetahuan dan keterampilan haruslah menjadi prioritas utama dengan harapan tujuan pembelajaran yang disampaikan benar-benar bisa tercapai.

Pendekatan pembelajaran saintifik pada Kurikulum 2013 tentu menjadi upaya yang efektif dalam mengembangkan aspek pengetahuan dan keterampilan peserta didik. Pembelajaran saintifik merupakan 
pembelajaran yang mengadopsi langkahlangkah ilmuwan dalam membangun pengetahuan melalui metode ilmiah. Pembelajaran saintifik tidak sekadar memperoleh kemampuan aspek pengetahuan, keterampilan dan sikap akan tetapi cenderung ke bagaimana pengetahuan keterampilan dan sikap itu diperoleh secara langsung oleh peserta didik dalam setiap proses pembelajaran. Salah satu model pembelajaran saintifik yang dapat diterapkan dalam pembelajaran PPKn dengan muatan materi Pendidikan Antikorupsi adalah model pembelajaran project citizen.

Pembelajaran project citizen merupakan pembelajaran yang dikembangkan di California pada tahun 1992 kemudian dikembangkan menjadi satu program nasional oleh Center for Civic Education (CCE)dan konferensi nasional badan pembuat Undangundang pada tahun 1995. Model pembelajaran project citizen merupakan model pembelajaran yang berbasis pada masalah untuk mengembangkan pengetahuan, kecakapan dan watak kewarganegaraan yang mendorong adanya tingkat partisipasi warga negara dalam sistem pemerintahan. Peran guru dalam model pembelajaran ini adalah sebagai instruktur dan fasilitator yang memberi pada peserta didik tentang sumbersumber informasi yang baru, membantu mengadakan kontak-kontak secara langsung dan membekali para peserta didik secara aktif dan kritis.

Model pembelajaran project citizen menitik beratkan pada keterlibatan peserta didik dalam proses pembelajaran secara keseluruhan baik aspek sikap, pengetahuan dan keterampilan. Berdasarkan dokumen CCE proses pembelajaran project citizen dikembangkan dalam suatu skenario dan rambu-rambu pembelajaran yang mencakup enam langkah sebagai berikut

1. Mengidentifikasi masalah kebijakan publik yang ada di dalam masyarakat; Pada langkah ini kelas difasilitasi untuk dapat mengidentifikasi berbagai masalah yang ada di lingkungan masyarakat dengan melalui pengamatan, wawancara, dan studi dokumentasi yang dilakukan secara kelompok.

2. Memilih masalah sebagai fokus kajian kelas. Pada langkah ini, kelas difasilitasi untuk mengkaji berbagai masalah itu dan kemudian memilih satu masalah yang paling layak untuk dipecahkan.

3. Mengumpulkan informasi terkait masalah yang menjadi fokus kajian kelas; Pada langkah ini kelas difasilitasi untuk mengumpulkan informasi yang diperlukan dalam rangka pemecahan masalah tersebut dari berbagai sumber informasi yang relevan dan tersedia, seperti perpustakaan, media massa, profesional dan ahli, pejabat pemerintahan, organisasi non pemerintah, dan tokoh serta anggota masyarakat.

4. Mengembangkan suatu portofolio kelas. Pada langkah ini, kelas mengembangkan portofolio berupa himpunan hasil kerja kelompok dalam rangka pemecahan masalah tersebut dan menyajikannya secara keseluruhan dalam bentuk panel pameran yang dapat dilihat bersama, yang melukiskan saling keterkaitan masalah, alternatif kebijakan, dukungan atas alternatif kebijakan, dan rencana tindakan untuk melaksanakan kebijakan tersebut.

5. Menyajikan portofolio kelas dalam suatu simulasi dengar pendapat; dan Pada langkah ini, keseluruhan portofolio yang telah dikembangkan kemudian disajikan dan dipamerkan kepada warga sekolah 
dan masyarakat. Melakukan kajian pengendapan atas pengalaman belajar yang dilakukan Pada langkah terakhir, kembali ke kelas untuk melakukan refleksi atau pengendapan dan perenungan mengenai hasil belajar yang dicapai melalui seluruh kegiatan tersebut (Winataputra \& Budimansyah, 2007, pp. 1-2).

Model pembelajaran project citizen tentu sangat efektif apabila diterapkan pada mata pelajaran PPKn. Hal ini tentu berkaitan dengan aspek kecakapan kewarganegaraan yang di kembangkan dalam materi pembelajaran PPKn.

Melalui model pembelajaran project citizen ini peserta didik berusahan untuk membentuk identitas mereka secara mandiri dan membina hubungan kemasyarakatan (Budimansyah, 2008, p. 183). Model pembelajaran project citizen dalam pembelajaran PPKn pada Materi Sistem Hukum dan Peradilan Nasional di Indonesia diharapkan dapat berpengaruh terhadap penanaman nilai-nilai sikap antikorupsi dengan baik bagi para siswa SMA dalam memahami korupsi.

Hal ini sependapat dengan Cogan \& Derricott (1998) ada tiga komponen penting pada mata Pelajaran PPKn yakni civic knowledge yang berhubungan dengan pengetahuan warga negara, civic skill berkaitan pada kecakapan intelektual dan partisipatoris warga negara yang relevan, civic disposition merupakan watak kewarganegaraan yang mengisyaratkan pada karakter publik ataupun privat yang penting bagi pemeliharaan dan pengembangan demokrasi konstitusional. Karakter dan kompetensi kewarganegaraan yang diharapkan sesuai penjelasan di atas salah satunya adalah dengan menanamkan nilainilai anti korupsi sejak dini.
Berdasarkan pada latar belakang masalah sebagaimana diuraikan di atas, maka yang menjadi persoalan inti dan sekaligus menjadi fokus telaah dalam penelitian ini adalah bagaimana implementasi pendidikan antikorupsi pada mata pelajaran PPKn berbasis project citizen. Mengingat rumusan masalah tersebut di atas begitu luas maka secara khusus peneliti ingin mengungkapkan beberapa permasalahan sebagai berikut: (1) Bagaimana implementasi materi pendidikan antikorupsi pada mata pelajaran PPKn? (2) Bagaimana implementasi pendidikan antikorupsi pada mata pelajaran PPKn berbasis project citizen? Dengan demikian yang menjadi tujuan dari penelitian ini adalah pertama, mengetahui bagaimana memasukkan muatan materi pendidikan antikorupsi pada mata pelajaran PPKn. Kedua, untuk mengetahui bagaimana cara menerapkan model pembelajaran project citizen pada materi pendidikan antikorupsi yang sudah dimasukkan dalam muatan materi PPKn.

\section{Metode}

Penelitian ini merupakan penelitian deskriptif kualitatif. Penelitian ini dilakukan di SMA Muhammadiyah Ponorogo pada kelas X. Sumber data dalam penelitian ini terdiri dari kepala sekolah, waki kepala sekolah bidang kurikulum, guru mata pelajaran PPKn dan peserta didik. Teknik pengumpulan data dalam penelitian ini yaitu melalui observasi, wawancara dan dokumentasi. Teknik analisis data dalam penelitian ini dilakukan melalui tiga tahap dengan cara menggolongkan, mereduksi dan menghilangkan data yang tidak sesuai dengan tujuan penelitian, kemudian dipaparkan secara deskriptif. Tahap selanjutnya yaitu proses membuat kesimpulan sesuai dengan tujuan penelitian. 


\section{Hasil dan Pembahasan}

Proses pembelajaran PPKn tentu perlu dilakukan secara berkelanjutan dan sistematis. Pola pembelajaran yang sistematis dan terukur akan mengembangkan kompetensi keilmuan pada peserta didik. Proses transformasi nilai-nilai keilmuan pada peserta didik tentu menjadi tolak ukur ketercapaian tujuan pembelajaran yang akan dicapai. Implementasi Pendidikan antikorupsi pada mata pelajaran PPKn menggunakan model pembelajaran project citizen bisa dilakukan melalui beberapa tahapan.

Implementasi Materi Pendidikan Antikorupsi Pada Mata Pelajaran PPKn. Proses pengimplementasian materi pendidikan antikorupsi harus membuat beberapa unsur proses pelaksanaan hal ini bisa dilakukan melalui beberapa tahapan pelaksanaan, yakni pengembangan Kurikulum Pembelajaran PPKn.

Muatan materi yang dikembangkan dalam proses pembelajaran PPKn terdiri sistem hukum dan peradilan nasional yang diajarkan pada materi PPKn kelas X. Melalui materi ini dapat disisipkan materi tentang pengertian tindak pidana korupsi dengan tujuan peserta didik mampu memahami arti kata dan definisi korupsi secara tepat dan benar, peserta didik mampu menjelaskan sejarah korupsi dan pemberantasan korupsi di indonesia dengan benar serta peserta didik mampu menjelaskan bentuk-bentuk korupsi.

Sedangkan materi selanjutnya yang perlu di sampaikan pada peserta didik terdiri dari materi yang berhubungan dengan upaya dan peran serta pemberantasan korupsi dengan tujuan pembelajaran agar peserta didik mampu menjelaskan berbagai upaya pemberantasan korupsi, peserta didik mampu menjelaskan peran serta dalam upaya pemberantasan korupsi ke dalam kehidupan sehari peserta didik mampu memahami nilainilai anti korupsi

Melalui pembelajaran pendidikan antikorupsi pada peserta didik akan memberikan kontribusi lebih dalam mengembangkan nilai-nilai atau sikap antikorupsi pada peserta didik. Muatan materi pembelajaran pendidikan antikorupsi pada pembelajaran PPKn dilakukan melalui beberapa hal salah satunya menyiapkan perangkat pembelajaran, menyiapkan materi pembelajaran yang terdiri dari pertama, pengertian tindak pidana korupsi sampai dengan kedua, upaya dan peran serta dalam pemberantasan korupsi.

Kedua materi ini disampaikan pada pertemuan pertama dengan durasi 2 kali 45 menit. Hal ini bertujuan agar para peserta didik bisa menyerap berbagai masalah dan pemahaman mendasar tentang korupsi secara umum, sehingga dalam pertemuan kedua nanti peserta didik akan disodorkan berbagai masalah tentang korupsi untuk bisa diselesaikan melalui model pembelajaran project citizen. Dengan harapan peserta mampu mengimplementasikan pengetahuan Ilmu dalam materi pendidikan antikorupsi kedalam solusi dari masalah korupsi yang terjadi.

Pada dasarnya proses pengimplementasian materi-materi pendidikan antikorupsi pada mata pelajaran PPKn sudah dikembangkan secara umum dalam setiap pembelajaran yang dilakukan. Hal ini mengingat bahwa salah satu upaya yang perlu dilakukan lembaga sekolah khususnya guru mata pelajaran PPKn yakni bagai mana nilai-nilai konsep dasar dalam materi antikorupsi bisa dikembangkan dalam beberapa hal baik pengembangan kurikulum pembelajaran PPKn yang memuat materi pendidikan antikorupsi maupun proses 
pembelajaran yang dilakukan oleh guru sehingga masing-masing komponen dalam pembelajaran bisa disatukan secara menyeluruh dalam perangkat pembelajaran. Tujuan akhir dari proses pembelajaran ini yakni menyiapkan para generasi muda yang berjiwa global yakni warganegara global yang akan berfikir secara luas dalam penanggulangan korupsi. kewarganegaraan global akan menumbuhkan karakter generasi muda yang berfikir kritis tentang isu-isu global untuk bisa mengeksplorasi, mengembangkan dan mengekspresikan nilainilai dan pendapat mereka sendiri (Zahabioun, Yousefy, Yarmohammadian, \& Keshtiaray, 2013, p. 199).

Implementasi Pendidikan Antikorupsi pada mata pelajaran PPKn Berbasis Project Citizen merupakan model pembelajaran yang berbasis pada masalah untuk mengembangkan pengetahuan, kecakapan dan watak kewarganegaraan yang mendorong adanya tingkat partisipasi warga negara dalam sistem pemerintahan.

Ada beberapa tahapan dalam proses pembelajaran menggunakan project citizen setelah peserta didik memahami materi pada pertemuan kedua peserta didik diarahkan untuk dibagi menjadi kelompok-kelompok kecil, terdiri dari 4 siswa. Masing-masing kelompok kecil diberikan tugas untuk mencari informasi tentang masalah yang ada di sekitar. Kemudian Siswa melakukan identifikasi masalah dalam kehidupan seharihari melalui diskusi dalam kelas, bertanya/wawancara kepada orang tua/keluarga, membaca koran baik cetak maupun online, mendengarkan berita maupun menonton TV, mencari sumber informasi melalui internet. Dalam hal ini penelitian mengambil contoh tema besar tentang kurangnya transparansi biaya sekolah yang diambil secara demokrasi dari berbagai masalah yang paling penting untuk diselesaikan.

Setelah itu peserta didik dibagi menjadi lima kelompok. Empat kelompok untuk panel besar dan satu kelompok untuk bagian dokumentasi. Kelima kelompok itu dapat dijelaskan sebagai berikut. Kelompok 1 bertugas menjelaskan masalah yang akan dibahas, kelompok 2 yang mengevaluasi kebijakan alternatif, kelompok 3 yang mengembangkan solusi sebagai kebijakan kelas, kelompok 4 mengembangkan rencana tindakan. Kelompok kelima bertanggung jawab bagian dokumentasi. Masing-masing kelompok terdiri dari 5 siswa. Setelah terkumpul data-data dari masing-masing kelompok kemudian peserta didik menyusun panel portofolio dan dokumen. Kemudian dipresentasikan secara umum di dalam kelas sesuai dengan kajian tugas kelompok.

Melalui pembelajaran project citizen dalam pelajaran PPKn akan mengembang sifat dan nilai-nilai sikap antikorupsi pada peserta didik. Salah satu nilai yang bisa dikembangkan dalam proses pembelajaran pendidikan antikorupsi pada mata pelajaran PPKn yakni sikap kejujuran, kepedulian, kemandirian, kedisiplinan, tanggung jawab, kerja keras, kesederhanaan, keberanian dan keadilan. Nilai-nilai ini bisa di rasakan secara langsung manakala peserta didik mengikuti setiap proses pembelajaran yang berlangsung. Melalui proses pembelajaran ini peserta didik lebih kreatif dan berinovasi dalam mengembangkan setiap muatan materi pendidikan antikorupsi yang kemudian akan menjadi dasar bersikap dalam kehidupan sehari-hari, baik di lingkungan sekolah keluarga dan masyarakat.

Pengimplementasian pendidikan antikorupsi pada pembelajaran PPKn tentu 
akan menghasilkan sikap dan kepribadian peserta didik yang berkemajuan guna menyelesaikan setiap permasalahan tentang berbagai korupsi yang terjadi di Indonesia. Dengan adanya pendidikan antikorupsi yang diajarkan dalam jenjang sekolah menengah atas khususnya kelas $\mathrm{X}$ akan menjadi dasar keilmuan antikorupsi pada masa yang akan datang yang menonjolkan sikap-sikap antikorupsi. Implementasi ini akan menjadi rujukan bagi para guru untuk mengembankan pendidikan antikorupsi dalam pembelajaran PPKn di SMA yang didasarkan pada dua konsep yakni proses pembelajaran berbasis project citizen dengan langkah-langkah yang sudah dikembangkan secara sistematis serta hasil capaian akhir dari pembelajaran yakni tercapainya pemahaman akan nilai-nilai dan sikap antikorupsi.

\section{Simpulan}

Berdasarkan penelitian yang dikembangkan oleh peneliti, menghasilkan kesimpulan sebagai berikut.

1. Implementasi materi pendidikan antikorupsi pada mata pelajaran PPKn biasa dilakukan melalui beberapa tahap 1) mengembangkan kurikulum pembelajaran PPKn hal ini bisa disisipkan melalui materi sistem hukum dan peradilan nasional. Pada bab ini akan disisipkan pendidikan antikorupsi yakni materi tentang pengertian tindak pidana korupsi dan materi upaya dan peran serta pemberantasan korupsi. 2) Proses pembelajaran Pendidikan antikorupsi pada mata pelajaran PPKn bisa dilakukan dengan menyiapkan perangkat pembelajaran yang di dalamnya terdiri dari media, model project citizen dan bahan referensi lain baik, internet study lapangan maupun sumber kajian lain. Dalam proses pembelajaran dilakukan selama dua kali pertemuan untuk pertemuan pertama membahas tentang materi dasar pendidikan antikorupsi sedangkan pertemuan kedua sudah praktik pembelajaran menggunakan project citizen.

2. Implementasi pendidikan antikorupsi pada mata pelajaran PPKn berbasis project citizen akan menjadi dasar keilmuan yang bisa mewujudkan generasi yang memiliki sikap antikorupsi yang tinggi kritis dalam menyingkapi berbagai kasus korupsi. Penerapan tersebut dapat dilakukan melalui beberapa hal 1) Penerapan proses pembelajaran menggunakan model project citizen peserta didik diarahkan untuk mengkaji berbagai masalah tentang korupsi. Dari masing-masing masalah diambil yang paling penting untuk segera diselesaikan. Setelah ditemukan masalah utamanya baru dibentuk kelompok besar yang terdiri dari empat komponen kelompok 1 - menjelaskan masalah yang akan dibahas, kelompok 2 mengevaluasi kebijakan alternatif, kelompok 3 - mengembangkan solusi sebagai kebijakan kelas, kelompok 4 mengembangkan rencana tindakan. Melalui proses ini maka akan muncul solusi dari masalah yang dibahas dan akan menjadi acuan untuk diselesaikan dengan bentuk panel presentasi project citizen. 2) Nilai-nilai dasar dari pendidikan antikorupsi akan dipahami secara langsung oleh peserta didik manakala melalui proses pembelajaran dengan model project citizen adapun nilai yang akan dicapai oleh peserta didik terdiri dari nilai kejujuran, kepedulian, kemandirian, kedisiplinan, tanggung jawab, kerja keras, kesederhanaan, keberanian dan keadilan. 


\section{Daftar Pustaka}

Budimansyah, D. (2008). Revitalisasi pembelajaran Pendidikan Kewarganegaraan melalui praktik belajar kewarganegaraan (project citizen). Civicus, 1(2), 179-189.

Cogan, J., \& Derricott, R. (Eds.). (1998). Citizenship for the 21st century: an international perspective on education. London: Kogan Page.

Hakim, L. (2012). Model integrasi pendidikan antikorupsi dalam kurikulum pendidikan Islam. Jurnal Pendidikan Agama Islam, 10(2), 141-156.

Hamilton-Hart, N. (2001). Anri-corruption strategies in Indonesia. Bulletin of Indonesian Economic Studies, 37(1), 6582.

Maftuh, B. (2008). Internalisasi nilai-nilai Pancasila dan nasionalisme melalui Pendidikan Kewarganegaraan. Educationist, II(2), 134-143. Retrieved from

http://103.23.244.11/Direktori/JURNAL/ EDUCATIONIST/Vol._II_No._2Juli_2008/7_Bunyamin_Maftuh_rev.pdf

Ministry of Education and Science of the Republic of Lithuania. (2006). Anticorruption education at school. methodical material for general and higher education school. Vilnius: Garnelis Publishing, Klaipèdos St. 6, LT01117.

Sax, G. (1997). Principles of educational and psychological measurement and evaluation. Washinton: Wadsworth publishing company.

Sutrisno. (2016). Peran ideologi Pancasila dalam perkambangan konstitusi dan sistem hukum di Indonesia. Jurnal Pancasila Dan Kewarganegaraan, 1(1), 41-49.

Wahab, A. A., \& Sapriya. (2011). Teori dan landasan Pendidikan Kewarganegaraan. Bandung: Alfabeta.
Winataputra, U. S., \& Budimansyah, D. (2007). Civic education konteks, landasan, lahan ajar, dan kultur kelas. Bandung: Sekolah Pascasarjana Universitas Pendidikan Indonesia.

Zahabioun, S., Yousefy, A., Yarmohammadian, M., \& Keshtiaray, N. (2013). Global citizenship education and its implications for curriculum goals at the age of globalization. Nternational Education Studies, 6(1), 195-206. https://doi.org/10.5539/ies.v6n1p195 